\title{
Genetic Variability of Different Morphological and Yield Contributing Traits in Different Accession of Saccharum Officinarum L
}

\author{
Smiullah $^{1}$, Farooq Ahmed Khan ${ }^{2}$, Usman Ijaz $^{1, *}$, Abdullah $^{1}$ \\ ${ }^{1}$ Ayub Agriculture Research Institute Faisalabad \\ ${ }^{2}$ Department of Plant Breeding \& Genetics, University of Agriculture Faisalabad \\ *Corresponding Author: usmanpbg@gmail.com
}

Copyright (C) 2013 Horizon Research Publishing All rights reserved.

\begin{abstract}
Ten genotypes of sugarcane (Saccharum officinarum L.) viz. COJ-84, CPF-235, COL-54, SPSG-26, COJ-64, SPF-232, CPF-237, S-97-US-297, KATHA and No-61 were evaluated for twelve characters and analyzed for genotypic and phenotypic correlation. Analysis of variance indicated highly significant differences exist for all the traits. Among the traits leaf area, number of tillers, cane thickness, and cane yield had the positive and significant correlation with brix value at both genotypic and phenotypic levels. Cane height had negative but non-significant correlation with brix value at genotypic and phenotypic level. Similarly cane weight had positive correlation both at genotypic and phenotypic level with cane height, number of tillers per plant and brix value. The study of path analysis for yield related traits depicted that cane height, cane thickness, leaf area, internodal length and brix value had the direct negative effects on yield.
\end{abstract}

Keywords Sugarcane, Cane Weight, Millable Cane, Cane Diameter, Dry Matter Contents, Correlation

\section{Introduction}

Sugarcane is an important industrial crop of tropical and subtropical regions is cultivated on 20 million ha in more than 90 countries. It accounts for around $60 \%$ the world's sugar (Khan et al., [1]). It is also an important cash crop in many developing/developed countries, because of its high trade value (Naz, [2]). The importance of sugarcane has increased in recent years because cane is an important industrial raw material for sugar and allied industries producing alcohol, acetic acid, butanol, paper, plywood, industrial enzymes and animal feed (Arencibia, [3]). It also has byproducts that provides raw material for local industry e.g. baggas used in paper industry as well as for chip board, alcohol obtained from molasses used in different medicines especially in homeopathic medicines. Ethanol is used in burning and disinfections. Sugar cane occupies significant position in agricultural economy of Pakistan. According to the economic survey of Pakistan [4], area under sugarcane grown is 1.04 million ha which, is $5.9 \%$ higher than the last year. In sugarcane growing countries, Pakistan ranks $5^{\text {th }}$ in cultivated area and $16^{\text {th }}$ in cane yield and the total production was estimated about 58 million tons with an average yield of 55.48 tons per ha. However, yield per hectare if, compared with last year posted a negative growth. Sugarcane shares in value added of Agriculture and GDP are 3.7\% and $0.8 \%$ respectively. The cane yield is decreasing due to non-availability of improved varieties. Breeding cultivars for higher yield in sugarcane is infancy especially in our region. Because chromosome numbers in somatic cells $(2 n)$ ranging from 80-124 in cultivated \& 48- 150 in wild types frequently aneuploid plant is impeded by complex genome and poor fertility but the most important is in-viable seed (fuzz) production due to the non availability of proper flowering conditions in Pakistan. For breeding purposes, fuzz is imported from abroad and only selection is done at sugarcane research institutes. In spite of spending heavy money on fuzz import, good sugarcane varieties are not produced, most of them are not high yielding, nothing is known about their genetic make up and variation present among the local collection of genotypes. In order to develop improved varieties, well planed breeding efforts are required. In Pakistan more efforts for tonnage while sucrose recovery remained low. In this crop, varietal improvement by using newly developed scientific concepts to bring out the maximum expression of yield potential possessed by varieties are the factors desiring more attention of the researchers. Various traits are accounted for variations in cane and sugar yields. Many of these character components are quantitatively inherited and inter-related with each other. Knowledge of interrelationship among the various characters is considered to be important in devising proper selection strategies in a sugarcane breeding DeSousa and Scott, [5]. Stevenson [6] pointed out that there may not be specific 
genes controlling the complex characters, but sum total effect of its component might be influencing the two most important characters, namely, cane yield and sucrose in sugarcane. Correlation coefficient analysis has been extensively used by plant breeders to obtain precise information on interrelationship among plant traits to better assess outcome of selecting one or more trait Furtado et al. [7]. The knowledge of association of cane and sugar yields with other traits helps breeders select suitable and desirable plant type. In multiple objective selections, correlation between characters in varying environmental conditions is of immense importance for overall response to selection. Pattern of association existing in the yield and quality components in subtropical environment has not been thoroughly examined over the years in this crop Tyagi et al. [8]. The result of present research will be helpful in planning future breeding programme for the evaluation of high yielding and better quality sugarcane varieties in Pakistan. The over all scope of study was to enhance the efficiency of selection. Correlation coefficient of yield contributing characters has always been helpful as basis for selection in breeding programs.

\section{Materials and Methods}

Study was carried out in Department of Plant Breeding \& Genetics, University of Agriculture, Faisalabad. Ten accessions of sugarcane COJ-84, CPF-235, COL-54, SPSG-26，COJ-64， SPF-232， CPF-237， S-97-US-297, KATA and No-61 were sown in 2011 in Randomized Complete Block Design with three replications. Plant to plant distance $30 \mathrm{~cm}$ and row to row distance was $75 \mathrm{~cm}$. All agronomic practices were followed. At maturity twenty five plants randomly selected in each replication for data collection. Cane height of selected plants were measured from ground level to top of the cane with the help of measuring tape in $\mathrm{cm}$ and number of tillers along with millable canes was counted. In the morning hours when leaf was fully turgid. Leaf area was calculated using the following function of Muller [9],

\section{Leaf area $=$ Leaf length $\times$ Leaf Width $\times 0.74$}

The length of the internodes in $\mathrm{cm}$ from three different places i.e. at the bottom, middle and top of the cane were taken with the help of meter rod along with number of nodes was counted. Vernier Calliper is used to measure the cane thickness from top, middle and bottom. The uppermost leafy portion and trash was removed to measure the cane weight. After measuring the cane weight, selected tillers were subjected to crusher and juice contents of each tiller were measured and with the help of hand refractometer brix value (\%) of juice was measured. The residues (Baggas) after juice extraction was weighted in fresh as well as sun dried (45 days) form to measure the baggas weight and dry matter contents. Data collected were subjected to statistical analysis of variance according to Steel et al. [10]. Genotypic and phenotypic correlation coefficients among the characters under study were estimated according to the statistical techniques outlined by Kown and Torrie [11] Path coefficient analysis was performed according to the method given by Dewey and $\mathrm{Lu}$ [12], in yield related traits keeping cane yield as resultant variable and yield related traits studied above as causal variable.

\section{Results and Discussion}

There were significant differences among the genotypes for all characters under studied (Table 1). This can be attributed to the fact that these clones were derived from parents having different genetic and geographic backgrounds.

\subsection{Correlation Studies}

The perusal of table 2 predicted that cane height showed negative correlation with leaf area, no of stools, no of millable canes and brix value which, is non-significant at both genotypic ( and phenotypic level. It was also found that association of cane height with cane diameter was positive and significant at genotypic (0.3879) but non-significant at phenotypic level (0.3456). similarly cane height had positive and significant correlation with internodal length, no of nodes, juice contents, baggas weight, dry matter and cane weight at genotypic level $(0.6582,0.6217,0.3134,0.4636$, 0.4519 and 0.5056 respectively) but positive and highly significant at phenotypic level with internodal length, no of nodes and cane weight $(0.6132,0.5230$ and 0.4877 respectively) whereas significant with baggas weight and dry matter (0.4477 and 0.4399). Das et al. [13] and Tyagi et al. [8] also found that cane height is positively and significant association with the cane weight, cane thickness and number of internodes. Leaf area had positive and significant correlation with all the traits studied at genotypic level (Table 2). 
Table 1. Mean of sum of square for stalk characteristics in ten sugarcane accessions

\begin{tabular}{|c|c|c|c|c|c|c|c|c|c|c|c|c|c|}
\hline Source & d.f & Cane height & $\begin{array}{l}\text { Tillers per } \\
\text { plant }\end{array}$ & $\begin{array}{l}\text { Millable } \\
\text { cane }\end{array}$ & $\begin{array}{l}\text { Leaf } \\
\text { area }\end{array}$ & $\begin{array}{l}\text { Internodal } \\
\text { length }\end{array}$ & $\begin{array}{l}\text { No. of } \\
\text { nodes }\end{array}$ & $\begin{array}{l}\text { Cane } \\
\text { diameter }\end{array}$ & Cane weight & Juice content & Brix Value & $\begin{array}{l}\text { Baggas } \\
\text { weight }\end{array}$ & $\begin{array}{l}\text { Dry matter } \\
\text { content }\end{array}$ \\
\hline Replication & 2 & 261.2 & $0.057^{\operatorname{ID}}$ & $0.31^{\text {rov }}$ & $305^{1 \mathrm{TV}}$ & $0.63^{\operatorname{ma}}$ & $1.98^{\mathrm{In}}$ & $0.013^{\operatorname{mo}}$ & 2296 & 331 & 1.20 & $93^{\ln }$ & $158^{\operatorname{In}}$ \\
\hline Genotype & 9 & $6031.96^{* *}$ & $21.91 * *$ & $8.6^{* *}$ & $34916^{* *}$ & $22.44 * *$ & $9.39 *$ & $0.25^{*}$ & $561960 * *$ & $167127^{* *}$ & $42.55 * *$ & $273344 * *$ & $54424 * *$ \\
\hline Error & 18 & 325.7 & 0.78 & 0.32 & 312 & 1.04 & 2.44 & 0.02 & 5221 & 2600 & 1.10 & 2883 & 599 \\
\hline
\end{tabular}

$* * P \geqslant 5 \%, * P \geqslant 1 \%, N S=$ Non Significant

Table 2. Genotypic and phenotypic correlation coefficients of all possible pairing of some characters of sugarcane plants

\begin{tabular}{|c|c|c|c|c|c|c|c|c|c|c|c|c|}
\hline Variables & $\begin{array}{l}\text { Cane } \\
\text { height }\end{array}$ & Leaf area & Tillers/plant & Millable canes & $\begin{array}{l}\text { Cane } \\
\text { thickness }\end{array}$ & $\begin{array}{l}\text { Internodal } \\
\text { length }\end{array}$ & No of nodes & Juice contents & $\begin{array}{l}\text { Baggas } \\
\text { weight }\end{array}$ & Dry matter & Brix value & Cane weight \\
\hline $\begin{array}{l}\text { Cane height } \\
\mathrm{rg} \\
\mathrm{rp}\end{array}$ & $\begin{array}{l}1.00 \\
1.00 \\
\end{array}$ & $\begin{array}{l}-0.0003 \mathrm{~ns} \\
-0.0045 \mathrm{~ns} \\
\end{array}$ & $\begin{array}{l}-0.2858 \mathrm{~ns} \\
-0.2794 \mathrm{~ns} \\
\end{array}$ & $\begin{array}{l}-0.1659 \mathrm{~ns} \\
-0.1634 \mathrm{~ns} \\
\end{array}$ & $\begin{array}{l}0.3879 * \\
0.3456 \mathrm{~ns}\end{array}$ & $\begin{array}{l}0.6582 * \\
0.6132 * *\end{array}$ & $\begin{array}{l}0.6217^{*} \\
0.5230^{* *}\end{array}$ & $\begin{array}{l}0.3134^{*} \\
0.2920 \mathrm{~ns}\end{array}$ & $\begin{array}{l}0.4636^{*} \\
0.4470^{*}\end{array}$ & $\begin{array}{l}0.4519^{*} \\
0.4399^{*}\end{array}$ & $\begin{array}{l}-0.0405 n s \\
-0.0424 n s \\
\end{array}$ & $\begin{array}{l}0.5056^{*} \\
0.4877^{* *} \\
\end{array}$ \\
\hline $\begin{array}{l}\text { Leaf area } \\
\mathrm{rg} \\
\mathrm{rp}\end{array}$ & & $\begin{array}{l}1.00 \\
1.00 \\
\end{array}$ & $\begin{array}{l}0.2933^{*} \\
0.2955 \mathrm{~ns} \\
\end{array}$ & $\begin{array}{l}0.2244 * \\
0.2130 \mathrm{~ns} \\
\end{array}$ & $\begin{array}{l}0.7243 * \\
0.7007 * *\end{array}$ & $\begin{array}{l}0.0793^{*} \\
0.737 \mathrm{~ns}\end{array}$ & $\begin{array}{l}0.2872 * \\
0.2364 \mathrm{~ns} \\
\end{array}$ & $\begin{array}{l}0.5030^{*} \\
0.5006^{* *} \\
\end{array}$ & $\begin{array}{l}0.0449^{*} \\
0.0414 \mathrm{~ns}\end{array}$ & $\begin{array}{l}0.1006^{*} \\
0.1020 \mathrm{~ns}\end{array}$ & $\begin{array}{l}0.5436^{*} \\
0.5351^{* *}\end{array}$ & $\begin{array}{l}0.2917 * \\
0.2871 \mathrm{~ns} \\
\end{array}$ \\
\hline $\begin{array}{l}\text { Tillers/plant } \\
\text { rg } \\
\mathrm{rp}\end{array}$ & & & $\begin{array}{l}1.000 \\
1.000 \\
\end{array}$ & $\begin{array}{l}0.8995^{*} \\
0.8548^{* *} \\
\end{array}$ & $\begin{array}{l}0.2166 \mathrm{~ns} \\
0.2021 \mathrm{~ns} \\
\end{array}$ & $\begin{array}{l}-0.1097 \mathrm{~ns} \\
-0.1086 \mathrm{~ns} \\
\end{array}$ & $\begin{array}{l}-0.3691 \mathrm{~ns} \\
-0.3818^{*} \\
\end{array}$ & $\begin{array}{l}-0.0265 \mathrm{~ns} \\
-0.0236 \mathrm{~ns} \\
\end{array}$ & $\begin{array}{l}0.2921^{*} \\
0.2824 \mathrm{~ns}\end{array}$ & $\begin{array}{l}0.2457^{*} \\
0.2315 \mathrm{~ns} \\
\end{array}$ & $\begin{array}{l}0.3476^{*} \\
0.3427 \mathrm{~ns} \\
\end{array}$ & $\begin{array}{l}0.1632^{*} \\
0.1565 \mathrm{~ns} \\
\end{array}$ \\
\hline $\begin{array}{l}\text { Millable canes } \\
\text { rg } \\
\mathrm{rp}\end{array}$ & & & & $\begin{array}{l}1.000 \\
1.000\end{array}$ & $\begin{array}{l}0.4700^{*} \\
0.4450^{*}\end{array}$ & $\begin{array}{l}-0.3189 \mathrm{~ns} \\
-0.3037 \mathrm{~ns}\end{array}$ & $\begin{array}{l}-0.1656 \mathrm{~ns} \\
-0.1135 \mathrm{~ns}\end{array}$ & $\begin{array}{l}-0.1648 \mathrm{~ns} \\
-0.1712 \mathrm{~ns}\end{array}$ & $\begin{array}{l}0.2774 * \\
0.2682 \mathrm{~ns}\end{array}$ & $\begin{array}{l}0.3080^{*} \\
0.3044 \mathrm{~ns}\end{array}$ & $\begin{array}{l}0.5297 * \\
0.5143 * *\end{array}$ & $\begin{array}{l}0.0771^{*} \\
0.0774 \mathrm{~ns}\end{array}$ \\
\hline $\begin{array}{l}\text { Cane thickness rp } \\
\mathrm{rg}\end{array}$ & & & & & $\begin{array}{l}1.000 \\
1.000 \\
\end{array}$ & $\begin{array}{l}-0.0601 \mathrm{~ns} \\
-0.0720 \mathrm{~ns} \\
\end{array}$ & $\begin{array}{l}0.4837^{*} \\
0.4397^{*} \\
\end{array}$ & $\begin{array}{l}0.1612 * \\
0.1655 \mathrm{~ns} \\
\end{array}$ & $\begin{array}{l}0.3703^{*} \\
0.3422 \mathrm{~ns} \\
\end{array}$ & $\begin{array}{l}0.4577^{*} \\
0.4373^{*} \\
\end{array}$ & $\begin{array}{l}0.6016^{*} \\
0.5852^{* *} \\
\end{array}$ & $\begin{array}{l}0.3508^{*} \\
0.3292 \mathrm{~ns} \\
\end{array}$ \\
\hline $\begin{array}{l}\text { Internodal length } \\
\mathrm{rp} \\
\mathrm{rg}\end{array}$ & & & & & & $\begin{array}{l}1.000 \\
1.000 \\
\end{array}$ & $\begin{array}{l}0.1665 \mathrm{~ns} \\
0.1707 \mathrm{~ns} \\
\end{array}$ & $\begin{array}{l}0.7477 * \\
0.7165 * * \\
\end{array}$ & $\begin{array}{l}0.5760^{*} \\
0.5584 * *\end{array}$ & $\begin{array}{l}0.5132 * \\
0.4999 * * \\
\end{array}$ & $\begin{array}{l}0.1145^{*} \\
0.1094\end{array}$ & $\begin{array}{l}0.7959^{*} \\
0.7794 * *\end{array}$ \\
\hline $\begin{array}{l}\text { No of nodes } \\
\text { rg } \\
\mathrm{rp}\end{array}$ & & & & & & & $\begin{array}{l}1.000 \\
1.000\end{array}$ & $\begin{array}{l}0.2392^{*} \\
0.2046 \mathrm{~ns}\end{array}$ & $\begin{array}{l}-0.1016 \mathrm{~ns} \\
-0.0977 \mathrm{~ns}\end{array}$ & $\begin{array}{l}-0.1158 \mathrm{~ns} \\
-0.0670 \mathrm{~ns}\end{array}$ & $\begin{array}{l}0.2955^{*} \\
0.2507 \mathrm{~ns}\end{array}$ & $\begin{array}{l}0.638^{*} \\
0.0490 \mathrm{~ns}\end{array}$ \\
\hline $\begin{array}{l}\text { Juice contents rg } \\
\text { rp }\end{array}$ & & & & & & & & $\begin{array}{l}1.000 \\
1.000 \\
\end{array}$ & $\begin{array}{l}0.3132 * \\
0.3111 \mathrm{~ns} \\
\end{array}$ & $\begin{array}{l}0.4025^{*} \\
0.4006^{*} \\
\end{array}$ & $\begin{array}{l}0.4821^{*} \\
0.4752^{* *} \\
\end{array}$ & $\begin{array}{l}0.7584^{*} \\
0.7490^{* *} \\
\end{array}$ \\
\hline $\begin{array}{l}\text { Beggas weight rg } \\
\text { rp }\end{array}$ & & & & & & & & & $\begin{array}{l}1.000 \\
1.000 \\
\end{array}$ & $\begin{array}{l}0.9695 * \\
0.9597 * * \\
\end{array}$ & $\begin{array}{l}0.3739^{*} \\
0.3638^{*} \\
\end{array}$ & $\begin{array}{l}0.8669^{*} \\
0.8615^{* *} \\
\end{array}$ \\
\hline $\begin{array}{l}\text { Dry matter } \\
\text { rg } \\
\text { rp }\end{array}$ & & & & & & & & & & $\begin{array}{l}1.000 \\
1.000 \\
\end{array}$ & $\begin{array}{l}0.5164 * \\
0.5064 * *\end{array}$ & $\begin{array}{l}0.8945^{*} \\
0.8853^{* *}\end{array}$ \\
\hline $\begin{array}{l}\text { Brix value } \\
\text { rg } \\
\mathrm{rp}\end{array}$ & & & & & & & & & & & $\begin{array}{l}1.000 \\
1.000\end{array}$ & $\begin{array}{l}0.5105^{*} \\
0.4999^{* *}\end{array}$ \\
\hline $\begin{array}{l}\text { Cane weight rg } \\
\text { rp }\end{array}$ & & & & & & & & & & & & $\begin{array}{l}1.000 \\
1.000\end{array}$ \\
\hline
\end{tabular}


$*_{\mathrm{rg}}=$ Genotypic correlations

$*_{\mathrm{rp}}=$ Phenotypic correlations

Table 3. Direct and Indirect Effects of Plant Traits on cane weight (dependent variable)

\begin{tabular}{|c|c|c|c|c|c|c|c|c|c|c|c|}
\hline Variables & Cane height & Leaf area & No. of tillers & $\begin{array}{l}\text { No. of } \\
\text { millable canes }\end{array}$ & Cane thickness & Internodal length & No of nodes & Juice contents & Baggas weight & Dry matter & Brix value \\
\hline Cane height & -0.0768 & -0.0007 & 0.03267 & -0.0188 & -0.0064 & -0.0781 & 0.0488 & 0.2155 & 0.4001 & -0.0171 & 0.0059 \\
\hline Leaf area & 0.0002 & -0.0030 & -0.0341 & 0.0254 & -0.0120 & -0.0094 & 0.0226 & 0.3458 & 0.0388 & -0.0040 & -0.0791 \\
\hline No. of tillers & 0.0219 & -0.0009 & -0.1143 & 0.1021 & -0.0360 & 0.0130 & 0.0290 & -0.0182 & 0.2520 & -0.0093 & -0.0506 \\
\hline No. of millable canes & 0.0127 & -0.0006 & -0.1028 & 0.1135 & -0.0077 & 0.03786 & -0.0130 & -0.1133 & 0.2393 & -0.0117 & -0.0771 \\
\hline Cane thickness & -0.0297 & -0.0021 & -0.0247 & 0.0534 & -0.0165 & 0.0071 & 0.03802 & 0.1108 & 0.3195 & -0.0173 & -0.0876 \\
\hline Internodal length & -0.0506 & -0.0003 & 0.0125 & -0.0361 & 0.0009 & -0.1187 & 0.0131 & 0.5140 & 0.4970 & -0.0194 & -0.0167 \\
\hline No of nodes & -0.0477 & -0.0008 & 0.0421 & -0.0187 & -0.0080 & -0.0198 & 0.0786 & 0.1644 & -0.0876 & 0.0044 & -0.0430 \\
\hline Juice contents & -0.0241 & -0.0015 & 0.0030 & -0.0187 & 0.0027 & -0.0888 & 0.0188 & 0.6875 & 0.2702 & -0.0152 & -0.0702 \\
\hline Baggas weight & -0.0356 & -0.0001 & -0.0334 & 0.0314 & -0.0601 & -0.0683 & -0.0080 & 0.2153 & 0.8628 & -0.0367 & -0.0545 \\
\hline Dry matter & -0.0347 & -0.0003 & -0.0281 & 0.0350 & -0.0075 & -0.0610 & -0.0091 & 0.2767 & 0.8365 & -0.0379 & -0.0752 \\
\hline Brix value & 0.0031 & -0.0016 & -0.0039 & 0.0601 & -0.0099 & -0.0136 & 0.0232 & 0.3314 & 0.3225 & -0.0195 & -0.1456 \\
\hline
\end{tabular}


While, at phenotypic level leaf area is positive and non significant in relation to all studied traits except cane thickness, juice contents and brix value $(0.7007,0.5006$ and 0.5351 respectively).

The perusal of Table 2 indicated that number of tillers per plant showed negative and non significant association with internodal length, number of nodes and juice contents at genotypic (-0.1097, -0.369 and -00265$)$ level and same for internodal length and juice contents at phenotypic (-0.1086 and -0.0236) level. While, at genotypic level with all other studied traits it showed positive and significant association but positively non significant with cane thickness, baggas weight, dry matter, brix value and cane weight $(0.2021$, $0.2824,0.2315,0.3427$ and 0.1565). Cane diameter associated with no of tillers was positive and non significant at both genotypic and phenotypic level. It was revealed from Table 2 that no of millable canes at genotypic level showed a negative and non significant association with internodal length, number of nodes and juice content $(-0.3189,-0.1656$ and -0.1648 ) while it is positive and significant for the remaining traits. At phenotypic level number of millable canes are non significant, negatively with internodal length, number of nodes and juice contents $(-0.3037,-0.1135$ and -0.1712) and positive with baggas weight, dry matter and cane weight (0.2682, 0.3044 and 0.0774). Similarly, Das et al. [13] investigated a positive correlation of millable canes with cane weight. Some scientists like Pillai et al. [14], Singh et al. [15] and Abdelmahmoud et al. [16] have reported a highly significant positive association between cane yield and three of its components (number of tillers, cane weight and cane length). It can be clearly seen (Table 2) that out of remaining associations, five associations i.e. between cane weight and internodal length ( $\mathrm{rp}=+0.7959, \mathrm{rg}=+0.7754)$, between cane weight and juice contents $(\mathrm{rp}=+0.7584$, $\mathrm{rg}=$ $+0.7490)$, between cane weight and baggas weight ( $\mathrm{rp}=$ $+0.8669, \mathrm{rg}=+0.8615)$, cane weight and dry matter ( $\mathrm{rp}=$ $+0.8945, \mathrm{rg}=+0.8615)$ and cane weight with brix value $(\mathrm{rp}=$ $+0.5105, \mathrm{rg}=+0.4999$ ) were found to be either significant or highly significant in nature. While brix value showed positive and significant correlation with cane thickness ( $\mathrm{rp}=$ $+0.6016, \mathrm{rg}=+0.5852)$, juice contents $(\mathrm{rp}=+0.4821, \mathrm{rg}=$ $+0.4752)$, baggas weight ( $\mathrm{rp}=+0.3739, \mathrm{rg}=+0.3638)$ and dry matter $(\mathrm{rp}=+0.5164, \mathrm{rg}=+0.5064)$. Rao and Krishnamoorthy [17] stated that sugarcane plant type should be one having uniform maximum number of tillers of a minimum height consistent with thickness and weight. Tyagi et al. [8] also found that the cane yield was positively correlated with all the yield and morphological plant attributes

\subsection{Path Coefficient Studies}

Path coefficient analysis unfolds whether the association of cane yield with its components is due to the direct effects of component characters on cane yield or is a consequence of its indirect effects via some other traits. The highest positive direct effect on cane yield was exerted by baggas weight
(0.8628) followed by juice contents, number of millable canes and number of nodes $(0.6875,0.1135$ and 0.0786 respectively). Chaudhry and Singh [18] and Chaudhry and Joshi [19] also found that millable canes and number of nodes has a direct effect on cane production. It is clearly seen from the table 3 that plant height, leaf area, number of tillers, cane thickness, internodal length, dry matter and brix value did not have any direct effect on the cane yield while, these traits have contributed to the cane yield via some other traits. Chaudhry and Joshi [19] found that number of internodes and length of internodes have a negative effect at the cane yield.

\section{Conclusions}

The cane yield is decreasing due to non-availability of improved varieties and sugar recovery. There is need to increase sugarcane production but efficient breeding in sugarcane is a problem in whole world especially in our region. In Pakistan more efforts are for tonnage while sucrose recovery remained low. Now we are focusing to increase sucrose recovery to meet the sugar requirement in country. Path coefficient study is very important as it measures the amount of contribution either directly or indirectly and also the percentage contribution of each parameter to the stalk. Therefore, the information quite useful when selecting for sugarcane and sugar yields. These results are applicable to parents studied in that particular environment. These parents can be used to produce high cane yielding and better sugar producing varieties of sugarcane.

\section{REFERENCES}

[1] Khan, F.A., M.Y. Iqbal and M. Sultan. 2007. Morphogenetic behavior of some agronomic traits of sugarcane (Saccharum officinarum L.). Pak. J. Agric. Sci., 44(4).

[2] Nazi, S. 2003. Micropropagation of promising varieties of sugarcane and their acclimatization response. Activities on Sugar Crops in Pakistan. In: Proc. Fourth Workshop Res. Dev., 1-9.

[3] Arencibia, A. 1998. Gene transfer in sugarcane. In: Biotechnology of Food Crops in Developing Countries. (Eds.): T. Hohn and K.M. Leisinger. Springer-Verlag, New York, pp.79-104.

[4] Economic survey of Pakistan. 2012. Govt. Of Pakistan finance and economic affairs division, Islamabad Pakistan.

[5] De Sousa-V. O. and M. B. Scott. 2005. Interrelationship of cane yield components and their utility in sugarcane family selection: Path coefficient analysis. INCI. 30(2):93-96.

[6] Stevenson, G.C. 1965. Genetics and Breeding of Sugarcane. Tropical Science Series. Longman's Green and Co., London.

[7] Furtado, M.R., C.D. Cruz, A.A. Cardoso, A.D. Fernandes and L.A. Peternelli. 2002. Análise de trilha do rendimento do 
feijoeiro e seus componentes primários em monocultivo e em consórcio com a cultura do milho. Ciência Rural. 32: 217-220.

[8] Tyagi, V.K., S. Sharma and S.B. Bhardwaj. 2012. Pattern of association among cane yield, sugar yield and their components in sugarcane (saccharum officinarum L.). J. Agric. Res. 50(1): 29-38.

[9] Muller, J. 1991. Determining leaf surface area by means of a wheat osmoregulation water use: the challenge. Agric. Meterolo. 14: 311-320.

[10] Steel R. G.D., J. H. Torrie and D. T. Deekey. 1997. Principles and practices of statistics: A biometrical approach, 3rd ed. McGraw Hill Book Co., Inc. New York.

[11] Kwon, S.H. and J. Torrie. 1964. Heritability and inter-relationship among traits of two soybean populations. Crop Sci., 4 : 196-198. [13] Das, P.K., B.C. Jena, N. Nayak, and A.K. Parida. 1996. Correlation and path analysis of cane yield in sugarcane. Crop. Sugar., 27(7): 509--512.

[12] Dewey, J.R. and K.H. Lu. 1959. A correlation and path co-efficient analysis of components of crested wheat seed production. Agron. J., 51: 515-518.
[13] Das, P.K., B.C. Jena, N. Nayak, and A.K. Parida. 1996. Correlation and path analysis of cane yield in sugarcane. Crop. Sugar., 27(7): 509--512.

[14] Pillai, S.V. and A.S. Ethirajan.1993. Correlation between yield and components at three stages of selection in sugarcane. Sugarcane. 4: 6-10.

[15] Singh, R.K., S.P. Singh and S.B. Singh. 2005. Correlation and path analysis in sugarcane ratoon Sugar Tech. 7(4): 176-178

[16] Abdelmahmoud,O. A., A. Obeid and B. Dafallah.2010, The influence of characters association on behaviour of sugarcane genotype (Saccharumspp.) for cane yield and juice quality. World J. Agric. Sci. 6(2): 207-211

[17] Rao, J.T. and T.N. Krishnamoorthi. 1968. Accelerating genetic improvement in sugarcane. Ind. J. Genet \& Plant Breed. 28 (A): 88-96.

[18] Chaudhary AK and JRP Singh. 1994. Correlation and path coefficient studies in early maturing clone of sugarcane (Saccharum spp. Complex). Cooperative Sugar 25: 305-307

[19] Chaudhry R.R. and B.K. Joshi. 2005. Correlation and path coefficient analysis in sugarcane. Nepal Agric. Res. J. 6: 24-27. 